JKM (Jurnal Kebidanan Malahayati),Vol 7,No.3.Juli 2021,

ISSN (Print) 2476-8944 ISSN (Online) 2579-762X, Hal 359-364

\title{
ANALISIS FAKTOR INTERNAL KINERJA BIDAN DALAM PELAYANAN KEBIDANAN BERKELANJUTAN
}

\author{
Liva Maita ${ }^{1}$ \\ 1Program S1 Kebidanan STIKes Hang Tuah Pekanbaru \\ email : livamaita@gmail.com
}

\section{ABSTRACT AN ANALYSIS OF INTERNAL FACTORS OF MIDWIFE PERFORMANCE IN SUSTAINABLE MIDWIFERY SERVICES}

Background: The Sustainable midwifery services (Continuity of care / CoC), which aim to determine fetal growth and maternal health, are provided starting from pregnancy, childbirth, postpartum, newborns, as well as the selection of a comprehensive family planning contraceptive method in order to be able to carry out early detection so that mothers and babies are healthy without any complications. The implementation of this service is related to the performance of midwives. The midwife performance can be influenced by internal factors, knowledge, namely training, attitudes, motivation, and skills. The Maternity Hospitals or Midwife Clinics should have implemented these sustainable Midwifery Services, but there are many obstacles faced, one of them isthe patient home visits that are still rarely carried out, which is influencedby the midwives' internal factors.

Objective: To find out how the internal factors which include knowledge, namely training, attitudes, motivation, and skills of midwives in sustainable midwifery services at Midwife Clinics in Pekanbaru city.

Method: The type of research is qualitative. The population of this study consists of 3 (three) senior midwives. The data collection techniques are through in-depth interviews, and documentation.

Results:The resondent interviews have not fully implemented the sustainable midwifery services, it is suggested for the organization to hold seminars on sustainable midwifery services.

Conclusion:The internal factors of midwife performance in sustainable midwifery services which include knowledge, namely training, attitudes, motivation, and skills of midwives in sustainable midwifery services, it can be concluded that the midwives have never attended training and seminars on sustainable midwifery services, so that the midwives are lack of knowledge in carrying out sustainable midwifery services maximally.

Suggestion:for the professional organizationis suggested to hold several trainings or seminars to midwives regarding the sustainable midwifery services.

Keywords: Analysis, Internal Factors, Midwife Performance, Sustainable Midwifery Services.

\section{ABSTRAK}

Latar Belakang : Pelayanan kebidanan secara berkesinambungan (Continuity of care/ CoC), yang bertujuan untuk mengetahui tumbuh kembang janin dan kesehatan ibu, yang diberikan mulai dari masa kehamilan, persalinan, nifas, bayi baru lahir, serta pemilihan metode kontrasepsi keluarga berencana secara komprehensif sehingga mampu untuk melakukan deteksi dini sehingga ibu dan bayi sehat tidak ada penyulit maupun komplikasi. Terselenggaranya pelayanan ini berkaitan dengan kinerja seorang bidan. Kinerja bidan dapat dipengaruhi oleh faktor internal yaitu pengetahuan, pelatihan, sikap, motivasi, dan keterampilan. Seyogyanya RB/BPM sudah melaksanakan Pelayanan Kebidanan berkelanjutan ini, akan tetapi banyak kendala yang dihadapi diantaranya kunjungan kerumah pasien yang masih jarang dilakukan salah satunya karena besarnya pengaruh dari faktor internal bidan

Tujuan: Untuk mengetahui bagaimana faktor internal antara lain pengetahuan, pelatihan, sikap, motivasi, dan keterampilan yang mempengaruhi kinerja bidan dalam pelayanan kebidanan berkelanjutan di PMB kota Pekanbaru

Metode: Jenis penelitian Kualitatif, responden dalam penelitian ini adalah bidan delima sebanyak 3 orang bidan. Teknik pengumpulan data melalui wawancara mendalam, dan dokumentasi.

Hasil: Wawancara belum seluruhnya melaksanakan pelayanan kebidanan berkelanjutan, saran diharapkan organisasi mengadakan seminar tentang pelayanan kebidanan berkelanjutan

Kesimpulan: Faktor internal bidan dalam pelayanan kebidanan berkelanjutan yang mencakup pengetahuan, pelatihan, sikap, motivasi, dan keterampilan dalam pelayanan kebidanan berkelanjutan maka 


\section{Liva Maita}

dapat disimpulkan Bidan belum pernah mengikuti pelatihan dan seminar tentang pelayanan kebidanan berkelanjutan sehingga menyebabkan pengetahuan bidan kurang untuk melakukan pelayanan kebidanan berkelanjutan secara maksimal

Saran : kepada Organisasi Profesi untuk dapat memberikan peyegaran berupa pelatihan atau seminar kepada para bidan mengenai pelayanan kebidanan berkelanjutan.

Kata Kunci : Analisis, Faktor Internal, Kinerja Bidan, Pelayanan Kebidanan Berkelanjutan

\section{PENDAHULUAN}

Pelayanan kebidanan merupakan bagian integral dari pelayanan kesehatan, yang diarahkan untuk mewujudkan kesehatan keluarga dalam rangka tercapainya keluarga yang berkualitas. Pelayanan kebidanan merupakan seluruh tugas yang menjadi tanggung jawab praktek profesi bidan dalam sistem pelayanan kesehatan yang bertujuan untuk meningkatkan kesehatan ibu dan anak dalam rangka mewujudkan kesehatan keluarga dan masyarakat, sehingga bidan dijadikan ujung tombak untuk meningkatkan derajat kesehatan ibu dan anak (Novianty, 2017).

Kesehatan ibu dan anak perlu mendapatkan perhatian karena ibu yang mengalami kehamilan dan persalinan mempunyai risiko terjadinya masalah yang dapat menyebabkan morbiditas dan mortalitas.(Simarmata,2012) Asuhan kebidanan secara berkelanjutan salah satu upaya untuk mendukung tujuan SDG'S (Sustanaible Development Goals) yang ketiga yakni memastikan kehidupan yang sehat dan mendukung kesejahteraan bagi semua untuk semua usia. Melalui asuhan yang tepat dan berkualitas dapat mendeteksi dini adanya risiko termasuk ketidaknyamanan dan komplikasi yang dialami ibu hamil, bersalin, nifas, bayi baru lahir dan neonatus. Hal ini dilakukan karena semua perempuan berisiko terjadinya ketidaknyamanan serta komplikasi selama masa hamil, bersalin dan nifas. Permasalahan yang sering timbul dengan adanya pengalaman negatif pada perempuan karena kurangnya kualitas interaksi antara bidan dengan perempuan ( Ningsih, 2017).

Di Provinsi Riau, angka kematian ibu (AKI) mengalami penurunan dengan jumlah kematian ibu pada tahun tahun 2017 sebanyak 119 orang, dan di tahun 2019 sebanyak 109 orang. Penyebab kematian ibu disebabkan oleh perdarahan sebanyak 34\%, hipertensi dalam kehamilan 33\%, infeksi $5 \%$ dan gangguan metabolic $1 \%$. Sekitar 15 $\%$ dari kehamilan/persalinan mengalami komplikasi yang keselamatanya tergantung pada ketepatan waktu dan kesiapan pelayanan kesehatan (Dinkes Provinsi Riau, 2018). Kesiapan dalam memberikan pelayanan salah satunya dengan menerapkan pelayanan kebidanan yang berkesinambugan (Contuinity of Care/CoC). (fitri,2020)

Bidan merupakan profesi kunci dalam pelayanan terhadap perempuan selama daur kehidupan dan mempunyai otoritas besar terhadap kesejahteraan kesehatan perempuan.(Pulungan,2020). Layanan kebidanan didasarkan pada pemenuhan kebutuhan perempuan, memberikan rasa nyaman dan bersikap yang baik serta kemampuan komunikasi yang baik.(Atik,2008) Pentingnya mendengarkan dari pihak perempuan memungkinkan dapat berkontribusi dalam pengambilan keputusan.(Prayitno,2013) Dalam model pelayanan kebidanan berkelajutan ini bidan meningkatkan peluang untuk memahami kehamilan, persalinan, nifas dan bayi baru lahir dan memastikan ibu mendapatkan pelayanan yang terbaik sehingga penggunaan intervensi pada ibu akan sedikit, dan tentunya ini sangat relevan dalam penurunan angka kematian ibu dan bayi (Yanti et al., 2015)

Kinerja seorang bidan dapat dipengaruhi oleh faktor internal yaitu pengetahuan, pelatihan, sikap, motivasi, dan keterampilan (Gibson, 2009). Dalam hal ini, bidan juga harus didukung dengan kompetensi inti bidan. Kompetensi inti yang dimaksud dalam hal ini adalah area klinis dalam praktik kebidanan yang dimana bidan memberikana asuhan komprehensif pada bayi, ibu hamil, bersalin, nifas, klimakterium, keluarga berencana, kesehatan reproduksi dan keterampilan klinis (Kemenkes RI, 2020)

Berdasarkan hasil studi pendahuluan terdapat 30 RB/BPM se-Kota Pekanbaru yang telah melakukan MoU dengan Pengurus Cabang IBI Kota Pekanbaru. Sebagian dari RB/BPM tersebut sudah menjadi bidan delima. Seyogyanya RB/BPM sudah melaksanakan Pelayanan Kebidanan berkelanjutan ini, akan tetapi banyak kendala yang dihadapi diantaranya kunjungan kerumah pasien yang masih jarang dilakukan, dan lain-lain. Dari fenomena yang ada maka peneliti tertarik untuk melakukan penelitian dengan judul "Analisis Faktor Internal Kinerja Bidan Dalam Pelayanan Kebidanan Berkelanjutan". 


\section{JKM (Jurnal Kebidanan Malahayati),Vol 7,No.3.Juli 2021, ISSN (Print) 2476-8944 ISSN (Online) 2579-762X, Hal 359-364}

\section{METODOLOGI PENELITIAN}

Metode penelitian ini adalah penelitian kualitatif dengan pendekatan metode deskriptif yang dilaksanakan di Bidan Delima Di Kota Pekanbaru. Adapun responden dalam penelitian ini adalah Bidan Delima di Kota Pekanbaru. Data yang dikumpulkan merupakan data primer yang diperoleh langsung dari informan melalui wawancara mendalam yang telah dipersiapkan sebelumnya serta melakukan observasi langsung di lapangan. Analisis data mengunakaan analisis kualitatif.

\section{HASIL DAN PEMBAHASAN}

Berdasarkan hasil wawancara dengan responden terkait tentang pengetahuan bidan tentang pelayanan kebidanan berkelanjutan di PMB Kota Pekanbaru hanya sebagian bidan yang mengungkapkan tentang pengetahuan yang benar. beliau memaparkan cara meningkatakan pengetahuan tersebut sebagaimana disebutkan oleh responden utama 1.

\section{Pengetahuan}

"Pelayanan kebidanan mencakup pelayanan ANC, INC, PNC terus bayi baru lahir" kalau ibu suka melihat internet mencari informasi-informasi mengenai kebidanan" (IU1)

Responden kedua menyatakan hal yang sama tentang pengetahuan pelayanan kebidanan berkelanjutan

"Eee...pelayanan yang menyeluruh lah ya..mulai dari hamil, bersalin sampai nifas terus kita pantau" sampai lahiran dan saya ketemu kasus sulit buka internet gimana cara penanganannya...tindakannya. pengalaman yang banyak akan membantu kita dalam memecahkan kasus".(IU2)

Responden ketiga menyatakan hal yang sama dengan Responden ke dua tentang pengetahuan pelayanan kebidanan berkelanjutan

"Tahu, CoC adalah pelayanan kebidanan berkelanjutan pada perempuan sejak masa kehamilan hingga post partum

Saya sering membuka internet untuk dapat info pengetahuan terbaru" (IU3)

\section{Pelatihan}

Berdasarkan hasil wawancara dengan responden terkait pelatihan yang pernah diikuti tentang pelayanan kebidanan berkelanjutan menunjukkan semua bidan belum pernah mendapatkan pelatihan dan seminar mengenai pelayanan kebidanan berkelanjutan

" Tidak pernah, kebanyakan tentang undang-undang dan peraturan kebidanan" tapi organisasi IBI mewajibkan kita misalnya ada arisan, seminar tu kita diingatkan kalau nolong partus tu harus dari A sampai $z$ harus dilakukan pemeriksaan, sangki tidak ada tapi nama kita dipanggil. dan IBI datang ke klinik melihat SOAP" (IU1)

Hal serupa juga disampaikan oleh responden kedua bahwa belum pernah dilakukan pelatihan tentang pelayanan kebidanan berkelanjutan.

"Rasanya tidak pernah ada pelatihan dan seminar tentang pelayanan kebidanan berkelanjutan, karena kami bidan delima...kan ada pertemuan jadi disitu ditanyakan SOAP kami. Cuma itulah masalahnya SOAP itu tidak sempat di pindahkan kecatatan masing-masing sekarang masih di dalam buku. "IU2)

Hal serupa juga disampaikan oleh responden ketiga bahwa belum pernah dilakukan pelatihan tentang pelayanan kebidanan berkelanjutan.

$$
\begin{aligned}
& \text { "Tidak ada.....tapi bu..IBI mewajibakan } \\
& \text { memberikan asuhan dan membuat } \\
& \text { SOAPsetiap pasien"(IU3) }
\end{aligned}
$$

\section{Sikap}

Berdasarkan hasil penelitian yang dilakukan melalui wawancara mendalam dengan responden yang terkait sikap bidan dalam melakukan pelayanan kebidanan berkelanjutan menunjukkan semua bidan melakukan sikap yang positif

"Saya berusaha memberikan pelayanan yang baik ke pasien..nah untuk tahu pasien puas dengan sikap saya biasanya pasien-pasien yang jauh-jauh akan datang mereka taunya ....pasien ni kan taunya dari mulut ke mulut pasien" (IU1)

Hal yang serupa juga diungkapakan oleh informen kedua bahwa bidan memberikan sikap yang positif terhdap pelayanan kebidanan berkelanjutan

"Jelas..pelayanan harus sebaik mungkin kita berikan, saya tidak akan bertanya...Cuma melihat..kalau dia kembali berarti dia puas....jelaskan semua yang dibutuhkan pasien...saya kasih no wa saya ke pasien. Kalau 
jaman sekarang posisi covid ini rasanya pasien lebih pintar dari kita, pasien fotokan, dia tunjukan tanyakan hampir setiap hari ibu bersalin itu akan bertanya. Rasanya sudah ideal...kalau hamil pun pasien bertanya. Kalau bersalin tidak buru-buru datang kemari, kalau nifas keluhan berat baru datang. Kalau kunjungan rumah pasien yang minta sekalian mandikan bayi. Pasien selalu wa kalau ada keluhan.(IU2)

Hal yang sama juga diungkapkan dengan responden ke tiga

"lya harus bu...pelayanan harus baik kita berikan ...Saya biasanya akan telepon pasien tanayakaan kondisi pasien...kalau pasien ada keluhan saya suruh datang ke klinik atau saya yang ketempat pasien kalau rumahnya dekat" (IU3)

\section{Motivasi}

Berdasarkan hasil penelitian yang dilakukan melalui wawancara mendalam dengan informen yang terkait Motivasi bidan dalam melakukan pelayanan kebidanan berkelanjutan menunjukkan semua bidan melakukan pelayanan kebidanan berkelanjutan dengan tujuan menurunkan angaka kematian ibu dan bayi

"Pertama tu...ANC harus teratur, yang kedua harus waspada pada kondisi pasien dan saya akan terus saya akan tetap ramah, senyum, dekat dengan pasien jangan cuek, pasien adalah raja" (IU1)

Hal yang serupa juga diungkapakan oleh informen kedua bahwa bidan mempunyai motivasi dalam pelayanan kebidanan berkelanjutan

"Saya sebenrnya kalau masih muda ni, lebih senang sebenarnya jalan ketempat ibu2 perumahan memberitahu ibu penyuluhan, kesekolah-kesekolah. Sebenarnya kita yang jemput bola Tapi waktu...(IU2)

Hal yang sama juga diungkapkan dengan responden ke tiga

"Bidan sebaiknya memberi pelayanan kebidanan, melakukan pemantauan ada tidaknya resiko tinggi terhadap ibu sejak masa kehamilannya hingga masa nifas" (IU3)
Keterampilan

Berdasarkan hasil penelitian yang dilakukan melalui wawancara mendalam dengan responden yang terkait keterampilan bidan dalam melakukan pelayanan kebidanan berkelanjutan menunjukkan tidak semua bidan melakukan pelayanan kebidanan berkelanjutan secara lengkap

"Ada, tapi pasien datang ke klinik. Kalau dulu waktu masih muda kita datang kerumah pasien, tapi kita sekarang menunggu pasien di klinik. Nifas itu harus dikunjungi sebenarnya sebanyak 4 kali, datang kerumah pasien, tapi sekarang tidak...karena faktor tenaga, waktu itu saja, seharunya kita berkunjung kerumah tapi sekarang tidak. (IU1)

Hal yang berbeda disampaikan oleh responden dua tentang keterampilan pelayanan kebidanan berkelanjutan bahwa bidan melakukan komunikasi melalui telepon jika pasien tidak berkunjung ke klinik

"O...malah kadang kadang pasien tu BPJS, kita tidak BPJS dia melahirkan $B P J S$, rata-rata balik ke klinik lagi,kadang kunjungan rumah malah kami, kalau ada keluhan dan kurangi 40 hari ke mari lagi. Kalau pasien nga datang via telepon meraka fotokan dan mereka datang kemari. Rata-rata 3 kali kunjungan mereka balik ke mari seiring dengan control anak untuk imunisasi" (IU2)

Hal yang sama juga disampaikan oleh responden tiga bahwa pelayanan kebidanan hanya dilakukan sampai ibu nifas terutama ibu nifas yang memiliki keluhan

"Oh...iya bu...pasien disini kalau periksa hamil, bersalin disini biasanya akan periksa nifas disini juga. Tapi kebanyakan pasien periksa nifas nya kalau ada keluahan saja bu baru datanag kalau nga ada keluhan periksanya pas saat jadwal imunisasi. Biasanya saya akan telepon pasien nanyakan kabar nya. Nga pernah sih sampai 4 kali kunjungan."(IU3)

\section{PEMBAHASAN \\ Pengetahuan}

Dari hasil penelitian yang dilakukan melalui wawancara mendalam di peroleh informasi pengetahuan bidan tentang pelayanan kebidanan 


\section{JKM (Jurnal Kebidanan Malahayati),Vol 7,No.3.Juli 2021, ISSN (Print) 2476-8944 ISSN (Online) 2579-762X, Hal 359-364}

berkelanjutan baik dimana bidan sudah dapat menyebutkan maksud dari pelayanan kebidanan berkelanjutan berdasarkan asuhan yang diberikan selama praktik hanya saja bidan belum jelas mendefinisikan pelayanan kebidanan berkelanjutan secara teoritis . Pelayanan kebidanan berkelanjutan (CoC) memberikan asuhan yang holistik dan berkelanjutan dan saling percaya antara bidan dan pasien mulai dari periode postnatal sampai masa bayi (Astuti, 2016). Dimensi pertama dari pelayanan kebidanan berkelanjutan yaitu dimulai saat kehamilan, pra kehamilan, selama kehamilan, persalinan, serta hari-hari awal dan tahun kehidupan. Dimensi kedua dari pelayanan kebidanan berkelanjutan yaitu tempat pelayanan yang menghubungkan berbagai tingkat pelayanan mulai dari rumah, masyarakat, dan sarana kesehatan. Dengan demikian bidan dapat memberikan asuhan secara berkelanjutan.

Berdasarkan pembahasan diatas asumsi peneliti bahwasanya pelayanan kebidanan berkelanjutan adalah pelayanan kebidanan yang berkesinambungan tanpa terputus untuk satu orang pasien mulai dari masa prakonsepsi sampai dengan bayi baru lahir sehingga bidan dapat memantau dan mendeteksi masalah yang terjadi pada pasien. Bidan dapat mencari sumber informasi tambahan melalui media internet untuk meningkatkan pengetahuannya.

\section{Pelatihan}

Dari hasil penelitian melalui wawancara mendalam diperoleh informasi tentang pelatihan yang diikuti ibu dan tentang pelayanan kebidanan berkelanjutan dimana semua bidan mengatakan belum pernah mendapakan pelatihan ataupun seminar mengenai pelayanan kebidanan berkelanjutan. Pelatihan dan pengembangan merupakan bagian dari suatu proses pendidikan yang bertujuan untuk meningkatkan kemampuan dan keterampilan khusus bagi seseorang atau sekelompok orang ( Ainy, 2016).

Berdasarkan pembahasan diatas asumsi peneliti bahwasanya pelatihan pelayanan kebidanan berkelanjutan belum dilakukan bidan karena memang organisasi profesi belum pernah mengusung tema untuk pelatihan ataupun seminar tentang pelayanan kebidanan berkelanjutan, sehingga para bidan hanya mengetahui pelayanan kebidanan berkelanjutan dari jenjang pendidikan saja, padahal organisasi profesi untuk bidan delima mengharuskan memberikan pelayanan tanpa terputus yang di buktikan dengan dokumentasi SOAP.

\section{Sikap}

Dari hasil penelitian melalui wawancara mendalam diperoleh informasi tentang sikap bidan tentang pelayanan kebidanan berkelanjutan dimana bidan sudah memberikan sikap positif dengan cara menanyakan kembali respon pasien terhadap pelayanan yang sudah diberikan (Aryanti,2018). Sikap merupakan reaksi atau respon yang masih tertutup terhadap suatu hal dalam hal ini pelayanan bidan. Manifestasi sikap itu tidak dapat langsung dilihat, tetapi hanya dapat ditafsirkan terlebih dahulu dari perilaku yang tertutup ( Notoadmojo, 2010)

Berdasarkan pembahasan diatas asumsi peneliti bahwasanya sikap bidan dapat dinilai dari respon pasien untuk kembali ke klinik. Pasien akan merasa nyaman memeriksakan kesehatannya apabila bidan memiliki sikap yang baik kepada pasien.

\section{Motivasi}

Dari hasil penelitian melalui wawancara mendalam diperoleh informasi motivasi bidan tentang pelayanan kebidanan berkelanjutan dimana bidan memiliki motivasi positif dalam melaksanakan pelayanan kebidanan berkelanjutan.(Surani,2008) Motivasi merupakan dorongan terhadap serangkaian proses perilaku manusia pada pencapaian tujuan. Motivasi meliputi unsur membangkitkan, mengarahkan, menjaga, menunjukkan intensitas, bersifat terus menerus dan adanya tujuan (Wibowo, 2014)

Berdasarkan pembahasan diatas asumsi peneliti bahwasanya motivasi bidan dalam pelayanan kebidanan bekelanjutan bertujuan menurunkan angka kematian ibu dan bayi dengan cara memberikan pelayanan terbaik kepada pasien, menambah wawasan ilmu kebidanan dan berpedoman pada peraturan dan perundangan dalam menjalankan praktik.

\section{Keterampilan}

Dari hasil penelitian melalui wawancara mendalam diperoleh informasi tentang keterampilan bidan tentang pelayanan kebidanan berkelanjutan dimana belum semua bidan menerapkan karena alasan waktu dan tenaga (Notoadmojo, 2010), mengatakan keterampilan merupakan aplikasi dari pengetahuan sehingga tingkat keterampilan seseorang berkaitan dengan tingkat pengetahuan.

Menjalankan tugas dan tanggung jawab secara profesional dengan melaksanakan fungsi sebagai bidan menuntut suatu keterampilan sebagai bidan yaitu merencanakan asuhan kebidanan sesuai dengan hasil pengkajian kebutuhan dan masalah kebidanan (Sri Astuti, 2017). Berdasarkan pembahasan diatas asumsi peneliti bahwasanya keterampilan bidan dalam 
mengasuh pasien mulai dari prakonsepi sampai dengan bayi baru lahir harus dilakukan secara bertanggung jawab dan profesional. Dimana asuhan nifas yang seharusnya dilakukan sebanyak empat kali hanya dilakukan apabila pasien mengalami keluhan. Pada masa pandemi ini, media komunikasi telepon, Whatsapp menjadi pilihan sehingga komunikasi bidan dan pasien tidak terputus. Keterampilan dalam mendokumentasikan asuhan juga menjadi tuntutan untuk bidan delima, asuhan yang berkelanjutan juga memiliki SOAP yang berkelanjutan, hal ini lah yang membuat bidan memiliki keterbatasan tenaga dan waktu dalam membuat laporan SOAP sehingga dokumentasi SOAP di buat sesederhana mungkin.

\section{SIMPULAN}

Pengetahuan bidan dalam pelayanan kebidanan berkelanjutan baik, hanya saja bidan belum dapat menjelaskan secara teoritis, bidan belum pernah mendapatkan pelatihan dan seminar tentang pelayanan kebidanan berkelanjutan, sikap bidan dalam pelayanan kebidanan berkelanjutan positif dimana bidan selalu menanyakan ke pasien tentang pelayanan yang sudah diberikan, motivasi bidan positif dan belum semua bidan menerapkan keterampilan pelayanan kebidanan berkelanjutan kepada pasien disebabkan waktu dan tenaga.

\section{SARAN}

Diharapkan kepada Organisasi Profesi untuk dapat memberikan peyegaran berupa pelatihan atau seminar kepada para bidan mengenai pelayanan kebidanan berkelanjutan dan memotivasi bidan untuk melakukan kembali pelayanan kebidanan berkelanjutan.

\section{DAFTAR PUSTAKA}

Atik Purwandari, A. M. (2008). Konsep kebidanan sejarah dan profesionalisme. EGC.

Ariyanti, D. (2018). FAKTOR PENENTU KINERJA BIDAN DALAM PELAYANAN NEONATUS DI PUSKESMAS GANDAPURA KABUPATEN BIREUEN TAHUN 2018 (Doctoral dissertation, INSTITUT KESEHATAN HELVETIA).

Asri Novianty. (2017). Buku ajar konsep kebidanan. In Jakarta: EGC.

Astuti. (2016). Konsep Kebidanan dan etikolegal dalam praktik kebidanan. Kemenkes RI.

Dewi Andariya Ningsih. (2017). Continuity of Care Kebidanan. OKSITOSIN: Jurnal IImiah Kebidanan, $\quad 4(2), \quad 67-77$. https://doi.org/10.35316/oksitosin.v4i2.362

Dinkes Provinsi Riau. (2018). Profil Kesehatan. Dinkes Provinsi Riau.
Fitri, F. J. (2020). ASUHAN KEBIDANAN CONTINUITY OF CARE DI KLINIK MEDIKA UTAMA SIDOARJO. Jurnal Kebidanan, 9(2), 34-43.

Gibson, J. L. (2009). Organisasi dan manajemen: perilaku, struktur, proses. Erlangga.

Kemenkes, \& RI. (202 C.E.). Standar Profesi Bidan. Kemenkes RI.

Notoatmodjo, S. (2010). Promosi kesehatan.

Prayitno, U. S., \& dan Informasi, P. P. P. D. (2013). Pemberdayaan masyarakat. P3DI Setjen DPR, Republik Indonesia dan Azza Grafika.

Pulungan, P. W., Rusmini, R., Zuheriyatun, F., Faizah, S. N., Kurniasih, H., Winarso, S. P., ... \& Utami, V. N. (2020). Teori Kesehatan Reproduksi. Yayasan Kita Menulis.

Qurratul Ainy. (2016). Analisis Faktro Yang Berhubungan Dengan Kinerja Bidan Dalam Pelayanan Antenatal Care di Wilayah Puskesmas Kabupaten Jember Tahun 2015. Universitas Jember.

Simarmata, O. S., Armagustini, Y., \& Bisara, D. (2012). Determinan kejadian komplikasi persalinan di Indonesia (analisis data sekunder survei demografi dan kesehatan Indonesia tahun 2007). Indonesian Journal of Health Ecology, 11(1), 79711.

Sri Astuti. (2017). Asuhan ibu dalam masa kehamilan. Erlangga.

Sukidjo Notoadmojo. (2010). Promosi Kesehatan dan IImu Perilaku. Rineka Cipta.

Surani, E. (2008). ANALISIS KARAKTERISTIK INDIVIDU DAN FAKTOR INTRINSIK YANG BERHUBUNGAN DENGAN KINERJA BIDAN PELAKSANA POLIKLINIK KESEHATAN DESA DALAM PELAYANAN KESEHATAN DASAR DI KABUPATEN KENDAL TAHUN 2007 (Analysis of Individual Characteristics and Intrinsic Factors related to Midwifeâ $s$ Work Performance at the Village Health Policlinic in Providing Basic Health Services in District of Kendal Year 2007) (Doctoral dissertation, Program Pascasarjana Universitas Diponegoro).

Utami, F. S., \& Putri, I. M. (2020). Konsep Pelayanan Prima Kebidanan.

Wibowo. (2014). Manajemen Kinerja (Ed.4). Raja Pers.

Yanti, Y., Claramita, M., Emilia, O., \& Hakimi, M. (2015). Students' understanding of 'WomenCentred Care Philosophy" in midwifery care through Continuity of Care $(\mathrm{CoC})$ learning model: a quasi-experimental study. BMC Nursing, $14(1), 22$. https://doi.org/10.1186/s12912-015-0072-z 